\title{
唾液腺腫瘍状病変における穿刺吸引細胞診施行例の検討
}

\author{
新 谷 悟 $\cdot$ 松 浦 秀 博 $\cdot$ 長谷川泰久 \\ 中山 敏 $\cdot$ 大竹智子
}

\section{An analysis of salivary gland masses obtained by fine needle aspiration biopsy}

\author{
Satoru Shintani $\cdot$ Hidehiro Matsuura $\cdot$ Yasuhisa Hasegawa \\ Bin Nakayama $\cdot$ Satoko Otake
}

\begin{abstract}
From April 1989 through March 1994, fine needle aspiration biopsies (FNAB's) were performed preoperatively in 43 patients with salivary gland masses (29 parotid, 12 submandibular, 2 sublingual) at the Department of Head and Neck Surgery, Aichi Cancer Center. Of the 43 salivary gland masses aspirated, 9 were maltgnant and 34 were benign. The sensitivity for FNAB in this study was $88.9 \%$. Among 9 malignant tumors, 6 were positive for malignancy, on FNAB, 2 were suspicious, and 1 was negative. The specificity was 94.1 $\%$, and the accuracy was $93.0 \%$. These results indicated that FNAB was a highly sensitive and specific screening procedure.

In salivary gland tumors, which were often morphologically heterogeneous, it was a disadvantage that FNAB specimens could derive cells only from a small area. However, this procedure was rapid, safe and relatively painless. Therefore, FNAB can be considered to be a simple, useful method for the initial screening diagnosis of salivary gland masses.
\end{abstract}

Key words: fine needle aspiration biopsy（穿刺吸引細胞診）, salivary gland tumors（唾液腺 腫陽）

緒言

穿刺吸引細胞診は Kun ${ }^{1)}$ により 1847 年に初めて報 告され, 1930 年には Martin ら ${ }^{2)}$ が頭頸部の腫瘤に 対しての報告を行っている. 1970 年代に入り Engzell らが, Fine needle aspiration biopsy (FNAB)に より, 優れた診断結果を報告し3), その後は, 主に欧 州において行われてきたが4，5) 1980 年代に入り，そ の正確さと安全性がアメリカにおいて報告されるよう になり 6 8), 唾液腺腫瘍に対しても用いられるよう になった ${ }^{9 \sim 11)}$. 術前に診断が得られるという利点に も関わらず, 正確な診断に十分な量の材料がとれない,

愛知県がんセンター頭頸部外科

(主任 : 松浦秀博部長)

Department of Head and Neck surgery, Aichi Cancer Center Hospital. (Cheif: Dr. Hidehiro Matsuura) 受付日: 平成 6 年 10 月 13 日
あるいは, 腫瘍の播種の危険性があるなどの指摘があ ることから 7,11 13), FNAB を敬遠する施設も多く, 本邦においてその報告は少ない14,15).

今回われわれは, 術前にFNABを施行した唾液腺 の腫瘍状病変について, その結果と手術材料における 病理組織診断を比較, 検討しその信頼度, 臨床的な有 用性などについて報告する。

\section{対象ならびに方法}

1989 年 4 月から 1994 年 3 月までの 5 年間に愛知照 がんセンター頭頸部外科で手術した喠液腺腫瘍状病変 のうち, 術前にFNABを施行した 43 例に対して, 検 討を行った. 部位は, 耳下腺 29 例, 顎下腺 12 例, 舌下 腺 2 例である (表 1 ). 年齢は, 18～74歳であり, 平均 49.5 歳で男 15 例, 女 28 例であった. 腫瘤の大きさ, 硬さ, 深さを十分に触診の後, 千葉大一外式穿刺吸引 装置を用い, $10 \mathrm{ml}$ のディスポシリンジに 21 ゲージの 
表 1 穿刺吸引細胞診 (FNAB) 施行例の部位別内訳

(愛知県がんセンター頭頸部外科, 1989-1994)

$\begin{array}{cr}\text { 耳下腺 } & 29 \text { 例 } \\ \text { 顎下腺 } & 12 \text { 例 } \\ \text { 舌 舌 腺 } & 2 \text { 例 }\end{array}$

表 2 穿刺吸引細胞診 (FNAB) ならびに組織学的診断 との関係

\begin{tabular}{cccc}
\hline \multirow{2}{*}{$\begin{array}{c}\text { 穿刺吸引細胞診 } \\
(\text { FNAB })\end{array}$} & \multicolumn{2}{c}{ 組織学的診断 } \\
\cline { 3 - 4 } & 悪性 $(9)$ & 良性 $(34)$ \\
\hline 陽 & 性 & 6 & 0 \\
疑 陽 性 & 2 & 2 \\
㓌 & 性 & 1 & 32 \\
\hline
\end{tabular}

ディスポ注射針をつけて穿刺し, シリンジの内筒を一 気に強く引いて強い㓌圧をかけ吸引した。局所麻酔は 使用しなかった：シリンジを針からはずし，針内に賠 留している細胞群をスライドグラスに吹き付けた後, ただちに固定液（95\%エチルアルコール）に容れ，通 常のパパニコロウ染色を施行した。診断は, 悪性か良 性かをパパニコロウ分類をもとに陰性，疑陽性，陽性 として判定するとともに，その組織型まで診断し，手 術材料による組織診断の結果と比較検討した. 感度は, 悪性病変における FNAB 陽性, 疑陽性例の割合とし， 特異性は良性病変における FNAB 陰性例の割合とし た。また，効率は全症例において正しく診断されてい る割合とした。

\section{結果}

大唾液腺の腫瘍状病変に対する 43 例の FNAB 施行 例中, 組織学的診断における良性病変は 34 例, 悪性 病変は 9 例であった. $6 / 43$ 例 $(14.0 \%)$ では, 一回の FNAB 時, 細胞採取不十分で再度, 穿刺を施行したが, 他の例では一回の穿刺で診断を行い得た．手術材料の 組織診断にて悪性であったもののうち，FNABにて 細胞所見に悪性を強く疑った陽性例は 6 例で, 異型細 胞を認め疑陽性としたものは 2 例，悪性がないとして 㓌性としたものが 1 例であり，陽性率は 88.9\%であっ た (表 $2 ， 3$ )。良性病変 34 例中, 疑陽性は 2 例, 陰性
表 3 穿刺吸引細胞診 (FNAB) の信頼性

$\begin{array}{ll}\text { 陽 性 率 } & 88.9 \% \\ \text { 特 異性 } & 94.1 \% \\ \text { 正診率 } & 93.0 \%\end{array}$

表 4 各組織学的診断における穿刺吸引細胞診 (FNAB) の正診率

\begin{tabular}{|c|c|c|}
\hline \multicolumn{3}{|l|}{ 良性 } \\
\hline 多形性腺腫 & $20 / 25$ & $(80.0 \%)$ \\
\hline Warthin 腫瘍 & $5 / 6$ & $(83.3 \%)$ \\
\hline 良性リンパ上皮性疾患 & $0 / 1$ & $(0 \%)$ \\
\hline \multirow[t]{2}{*}{ 炎症 } & $2 / 2$ & $(100 \%)$ \\
\hline & $27 / 34$ & $(79.4 \%)$ \\
\hline \multicolumn{3}{|l|}{ 悪性 } \\
\hline 腺癌 & $3 / 3$ & $(100 \%)$ \\
\hline 腺房細胞癌 & $0 / 1$ & $(0 \%)$ \\
\hline 悪性多形性腺腫 & $0 / 2$ & $(0 \%)$ \\
\hline 腺様囊胞癌 & $1 / 1$ & $(100 \%)$ \\
\hline 扁平上皮癌 & $1 / 1$ & $(100 \%)$ \\
\hline \multirow[t]{2}{*}{ 粘表皮癌 } & $1 / 1$ & $(100 \%)$ \\
\hline & $6 / 9$ & $(66.7 \%)$ \\
\hline
\end{tabular}

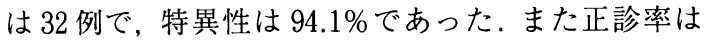
93.0\%であった（表 2，3 ). 悪性腫瘍における FNAB 誤陰性例は, 悪性多形性腺腫を, 多形性腺腫 (パパニ コロウ分類, Class II ) と診断したものであり, 疑陽 性の 2 例は, 悪性多形性腺腫ならびに腺房細胞癌を粘 表皮癌を疑いClass II と診断したものであった. 良性 病変の最終的な組織学的診断では, 多形性腺腫が 25 例と多く, War thin 腫瘍 6 例, 良性リンパ性腫瘍 1 例, 炎症 2 例であった. 悪性病変では腺癌 3 例, 悪性 多形性腺腫 2 例, 腺房細胞癌 1 例, 腺栏囊胞癌 1 例, 扁平上皮癌 1 例, 粘表皮癌 1 例であった。これら腫瘍 状病変において組織型まで正しく診断されていた割合 は良性腫瘍で $79.4 \%$, 悪性腫瘍で $66.7 \%$ あり, 全体 では $76.7 \%$ であった（表 4 ）。 
唾液腺腫湟に対する治療前の診断は, 重要で有意義 である。耳下腺における浅葉切除術は，良性腫瘍に対 して十分であっても，悪性腫瘍に対する切除範囲とし ては不十分であろう。顔面神経麻㾇, Frey 症候群の回 避などを含め，できるだけ十分な情報のもとで手術計 画はたてられるべきである，病歴，触診などに加え， 唾液腺造影, 超音波診断, X 線 CT, MR-CT あるい は RI シンチグラムなどの画像診断の進歩に伴い，唾 液腺腫瘍の診断は向上したが, 十分であるとは言えな い.FNABは, 術前に組織型が診断されうるという利 点にも関わらず，その価値ならびに意味あいが論争に なってきた ${ }^{6 \sim 13,16)}$. 唾液腺腫瘍に対して穿刺吸引に よる生検を敬遠する理由としては, 鉗除生検や切開生 検に対して言われていると同様の，被膜破裂による再 発, 転移促進, 検查後の瘦孔形成の可能性, 生検部位 癒着のための手術操作を困難にするなどの問題がある とされているが16，17)，現在，一般的に行われている 20ー25ゲージのいわゆる Fine needle を用いた $\mathrm{FNAB}^{3 \sim 11,18)}$ においてはこの問題はほとんどない と思われる. Frable ら ${ }^{7)}$ の文献的検討や Engzell ら ${ }^{13)}$ の多形性腺腫の FNAB 施行例 157 例に $10 \sim 15$ 年の経 過観察を行った報告でも腫瘍の播種などの問題はない としている，われわれの症例でも，FNABによる再発， 転移促進の例はなく, また, 手術時, 同部に癒着がみ られたなどもなかった。

FNAB の問題点に, 吸引時, 十分な組織採取が行い得 ない場合や，狭い限られた範囲からの材料であるため 診断が困難な場合があることがあげられる，本報告に おいても，43 例中 6 例 $(14.0 \%)$ で，細胞採取が不十 分であった．また，悪性病変において誤陰性の結果と なったものは, 病変の一部が悪性変化している悪性多 形性腺腫の症例であり,このように, 病理組織が多彩 であったり，囊胞を形成しているなどの形態学的な heterogeneity が問題となると考えられた。これらの 問題点に対しては, 目的とする病変の適切な部位から 材料を得るようにすることが大切であり，最近ではエ コーグラムを視ながら針先を誘導して，高輝度部位に 当てるなどの工夫が考えられている15).

本報告における FNAB の陽性率は $88.9 \%$ ，特異性 は 94.1\%であり，諸家の報告9－13，16）と同様に高い診 断率を示した. 組織型においても全体として $76.7 \%$ の 症例で正しい診断を得ており，比較的正確な情報を提 供すると思われた，また，従来言われてきたような合 併症は認めず，手技的にも安全で，比較的痛みを伴わ ず行い得ると考えられたことから，本法は唾液腺腫湯 の診断の一助になると考えられる.
結

論

1989 年 4 月から 1994 年 3 月までの 5 年間に愛知県 がんセン夕一頭頸部外科で手術を行った喠液腺腫瘍状 病変のうち, FNAB を施行した 43 例についてその結 果を検討した。

墨性腫湯 9 例中, FNAB 陽性 6 例, 疑陽性 2 例, 陰 性 1 例であり，陽性率は $88.9 \%$, 特異性は $94.1 \%$ で, 正診率は $93.0 \%$ であった。喠液腺の腫瘍状病変に対す るFNABによる診断は組織採取や形態学的な heterogeneity に起因する診断の誤りなどの問題はあるもの の, 安全で, 合併症が少なく, 比較的痛みを伴わない 方法であり，比較的正確な情報を提供することから， 喠液腺腫場の診断の一助になると考えられた。

\section{謝辞}

稿を終えるにあたり，御指導，御協力を賜つた愛知県 がんセンター臨床検査部越川 卓先生に深く感謝致しま す.

\section{引用 文 献}

1) Kun, M.: A new instrument for the diagnosis of tumours. Month J Med Sci 7 : 853-854 1847.

2) Martin, H. and Ellis, E. B.: Biopsy of needle puncture and aspiration. Ann Surg 92 : 169-182 1930.

3) Enzell, U., Jakobsson, P. A. et al.: Aspiration biopsy of metastatic carcinoma in lymph nodes of the neck. Acta Otolaryngol $72:$ 138-147, 1971.

4) Eneroth, C. M., Franzen, S. et al.: Cytological diagnosis on aspirate from 1000 salivary glands tumours. Acta Otolaryngology 224 : 168-171 1967.

5) Webb, A. J.: Cytologic diagnosis of salivary gland lesions in adult and paediatric surgical patients. Acta Cytology $17: 51-58$ 1973.

6) Frable, M. S. A., Frable, W. J.: Fine needle aspiration biopsy revisited. Laryngoscope 92 : 1414-1418 1982.

7) Frable, W. J. and Frable, M. S. A.: Thin needle aspiration biopsy. The diagnosis of head and neck tumors revisited. Cancer $43: 1541-15481979$.

8) Young, J. E. M., Archibald, S. D., et al.: Needle aspiration cytologic biopsy in head and neck masses. Am J Surg 142 : 484-489 1981.

9) Shaha, A. R., Webber, C., et al.: Needle aspiration biopsy in salivary gland 
lesions. Am J surg 160 : 373-376 1990.

10) O’Dwyer, P., Farrar, W. B., et al.: Needle aspration biopsy of major salivary gland tumours; its value. Cancer $57: 554-557$, 1986.

11) Zajicek, J., Eneroth, C. M., et al.: Aspiration biopsy of salivary gland tumours VI. Morphologic studies on smears and histologic sections from 24 cases with mucoepidermoid carcinomaa. Acta Cytology 20 : 35-41 1976.

12) Mavec, P., Eneroth, C. M., et al.: Aspiration biopsy of salivary gland tumors I. Correction of cytologic reports from 652 aspirations biopsies with clinical and histologic findings. Acta Otolaryngology $58:$ 471-484 1964 .

13) Engzell, V., Esposti, D. L. et al.: Investi- gation of tumour spread in connection with aspiration biopsy. Acta Radiology $10: 385-3981971$.

14）村上 泰: 穿刺吸引細胞診. JOHNS 4 ：891- 893. 1988.

15）丸山 效, 桜井 栄, 他: 超音波画像下細胞診 の新手法: 日耳鼻会報 $90: 1208-12161987$.

16) Illes, R. W., Brain, M. B.: A review of the tumours of the salivary gland. Surgery Gynaecology and Obsterics $163: 399-404$ 1986.

17）横尾恵美子：唾液腺の悪性腫瘍の診断. 清水正 嗣, 小浜源郁編 : 口腔癌. デンタルダイヤモン ド社, 東京, 1989, 186-192 頁

18) Linsk J. A. and Franzen S.: Clinical Aspiration cytology. J. B. Lippincott Co. Philadelphia, 1983, p $1-8$. 